\title{
EPIDEMIOLOGY OF DERMATITIS IN FARMERS
}

\section{Studi Epidemiologi terhadap Kejadian Dermatitis pada Petani}

\author{
Yarmaliza Yarmaliza ${ }^{1}$, Teungku Nih Farisni ${ }^{2}$, Fitriani ${ }^{3}$, Veni Nella Syahputri ${ }^{4}$, Zakiyuddin \\ Zakiyuddin $^{5}$, Fitrah Reynaldi ${ }^{6}$ \\ ${ }^{1}$ Faculty of Public Health, Universitas Teuku Umar, yarmaliza@utu.ac.id \\ ${ }^{2}$ Faculty of Public Health, Universitas Teuku Umar, teungkunihfarisni@utu.ac.id \\ ${ }^{3}$ Faculty of Public Health, Universitas Teuku Umar, fitriani@utu.ac.id \\ ${ }^{4}$ Faculty of Public Health, Universitas Teuku Umar,veninellasyahputri@utu.ac.id \\ ${ }^{5}$ Faculty of Public Health, Universitas Teuku Umar, zakiyuddin@utu.ac.id \\ ${ }^{6}$ Faculty of Public Health, Universitas Teuku Umar, fitrahreynaldi@utu.ac.id \\ Corresponding Author: Yarmaliza, yarmaliza@utu.ac.id, Faculty of Public Health, Universitas Teuku Umar, \\ Alue Peunyareng, Ujong Tanoh Darat, Meureubo, West Aceh, Aceh, 23681Indonesia
}

\section{ARTICLE INFO}

Article History:

Received July, 29 $9^{\text {th }}, 2019$

Revised form August, 28 ${ }^{\text {th }}, 2019$

Accepted January, 21 ${ }^{\text {st }}, 2020$

Published online January, 28 ${ }^{\text {th }}, 2020$

Keywords:

dermatitis;

contact with family;

personal hygiene;

cross sectional

\section{Kata Kunci:}

dermatitis;

kontak dengan keluarga;

personal hygiene;

cross sectional

\begin{abstract}
Background: Dermatitis refers to the inflammation of the skin and can be acute, sub-acute, or chronic. In 2014, there were 364 cases in Meureubo Health Center, which increased sharply to 1,854 cases in 2915 and 2,794 cases in 2016. Purpose: This study looks at the relationship between personal hygiene and a history of contact with families suffering from dermatitis and the incidence of dermatitis in farmers in West Aceh District. Methods: This research was conducted using a descriptive observational design and was carried out in the working area of the Meureubo Public Health Center (Puskesmas Meureubo) in West Aceh Regency between 5 December 2017 and 8 January 2018. A purposive sampling technique was used for the collection of primary and secondary data. Results: The majority of respondents were male (60\%), aged $31-40$ years $(66 \%)$, and had a low education level $(76 \%)$. The majority of farmers had poor personal hygiene $(61 \%)$ and had a history of contact with families suffering from dermatitis $(66 \%)$. Conclusion: There is a high prevalence of poor personal hygiene in farmers, and they tend to have a history of contact with family members suffering from dermatitis.
\end{abstract}

C2020 Jurnal Berkala Epidemiologi. Published by Universitas Airlangga. This is an open access article under CC-BY-SA license (https://creativecommons.org/licenses/by-sa/4.0/)

\section{ABSTRAK}

Latar Belakang: Penyakit dermatitis dapat diartikan sebagai sebuah peradangan non-inflamasi pada kulit yang bersifat akut, sub-akut, atau kronis dan dipengaruhi banyak faktor. Terjadi peningkatan kasus dari 2014 - 2016. Tujuan: Penelitian ini bertujuan untuk mengetahui kondisi personal hygiene dan riwayat kontak dengan keluarga yang menderita dermatitis dengan kejadian dermatitis pada petani di wilayah kerja Puskesmas Meureubo Kabupaten Aceh Barat. Metode: Penelitian ini dilakukan secara deskriptif observasional dan telah dilakukan di wilayah kerja Puskesmas Meureubo Kabupaten Aceh Barat pada tanggal 5 Desember 2017- 8 Januari 2018. Jumlah

\footnotetext{
How to Cite (APA): Yarmaliza, Y., Farisni, T. N, Fitriani, Syahputri, V. N., Zakiyuddin, Z., ... Reynaldi, F. (2020). Analysis study epidemiology of dermatitis diseases on the farmers. Jurnal Berkala Epidemiologi, 8(1), 50-56. https:/dx.doi.org/10.20473/ jbe.v8i12020.50-56
} 
populasi dalam penelitian ini sebanyak 1.089 orang dan sampel 95 orang, pemilihan sampel menggunakan teknik purposive sampling dan teknik pengumpulan data yaitu data sekunder dan primer, data dianalisis dengan menggunakan analisis univariat Hasil: Mayoritas responden berumur 31-40 tahun yaitu 36 orang (66,30\%), dengan jenis kelamin laki-laki sebanyak 57 responden (60,00\%). Mayoritas pendidikan responden berada pada tingkat pendidikan SD yaitu sebanyak 36 responden (76\%). Mayoritas petani memiliki kondisi personal hygiene yang kurang baik yaitu 58 responden (61\%), sedangkan kondisi petani yang mengalami riwayat kontak dengan keluarga yang menderita dermatitis yaitu 63 responden (66,30\%). Kesimpulan: Kondisi personal hygiene yang kurang baik pada petani dan petani yang mengalami riwayat kontak dengan keluarga yang menderita dermatitis sebanyak diatas $50 \%$.

(C)2020 Jurnal Berkala Epidemiologi. Penerbit Universitas Airlangga. Jurnal ini dapat diakses secara terbuka dan memiliki lisensi CC-BY-SA (https://creativecommons.org/licenses/by-sa/4.0/)

\section{INTRODUCTION}

Dermatitis and urticaria are occupational dermatoses. Contact dermatitis accounts for 50\% of all occupational diseases (OD), and most of them are nonallergic or irritant type. There are two types of contact dermatitis, such as irritant contact dermatitis, which is a nonimmunological response and allergic contact dermatitis, which is caused by specific immunologic mechanisms (Salawati, 2015). Both types can be acute or chronic. The causes of allergic contact dermatitis include chemicals in the tools used by the sufferer and materials in the vicinity of the sufferer (Wardani, Mashoedojo, \& Bustamam, 2018). Other factors that facilitate the onset of dermatitis are air temperature, humidity, friction, and occlusion (Alex, Longinus, Olatunde, \& Chinedu, 2018).

Data from the UK found 129 cases of occupational dermatitis per 1,000 workers. Almost all occupational dermatoses are contact dermatitis (95\%), while some are other skin diseases such as acne, contact urticaria, and skin tumors (Mrema, Ngowi, Kishinhi, \& Mamuya, 2017). Dermatitis usually affects people who have frequent contact with substances that are toxic or allergic, e.g. housewives, farmers, and workers who deal with chemicals (Malik \& English, 2015). A study by Negatu, Kromhout, Mekonnen, \& Vermeulen (2016) also concluded that personal hygiene influences the incidence of dermatitis.

Atopic dermatitis is also increasing in prevalence worldwide and is estimated to be around $15-30 \%$ in children and $2-10 \%$ in adults (Rahman, Sultana, Rahman, \& Bilgrami, 2015). The incidence of atopic dermatitis has doubled in the last three decades in industrialized countries, and according to the International Study of Asthma and Allergies in Childhood (ISAAC), its prevalence in children varies from 1 to $20 \%$, with the highest prevalence found in Northern Europe. The prevalence of atopic dermatitis in Asian children is yet to be widely reported, but the reported overall prevalence rates are $20 \%$ in Hongkong, $19 \%$ in Japan, and 21\% in Singapore (Chandarakesan, Muruhan, \& Sayanam, 2018).

The results of epidemiological studies in Indonesia have suggested that $97 \%$ of the 389 dermatitis cases are contact dermatitis, with $66 \%$ found to be Contact Dermatitis Irritant (CDI) and $34 \%$ allergic contact dermatitis (DKA) (Mekonnen, Yenealem, \& Tolosa, 2019). The incidence of occupational contact dermatitis is estimated at 0.50 to 0.70 cases per 1,000 workers per year in Indonesia (Dewi, Tina, \& Nurzalmariah, 2017), and skin diseases are estimated to account for 9-34\% of ODs. Occupational contact dermatitis usually occurs on the hands. The incidence rate for dermatitis in North American varies between $2 \%$ and $10 \%$, and it is estimated that $5 \%$ to $7 \%$ of dermatitis sufferers will develop chronic dermatitis (Kadivar $\&$ Belsito, 2015).

Data from the Aceh Health Service stated that many people complained of skin disease or dermatitis due to the floods that hit several districts in Aceh Province (Dinkes Aceh, 2016). According to data from the West Aceh District Health Office, there were as many as 8,076 dermatitis cases in 2016 , compared to 7,487 in 2015. In addition, many dermatitis cases were experienced by farmers who work in the fields and plantations. 
Based on data from the Meureubo Public Health Center (Puskesmas Meureubo), the number of dermatitis cases in farmers in 2014 was 364, which increased to 1,854 cases in 2015 and 2,794 cases in 2016 (West Aceh District Health Office, 2017).

Based on observations at the research location, dermatitis is common in farmers. This condition may occur due to lack of personal hygiene, for example, not taking a shower and changing clothes after work. Farmers also often use family bath towels, which can lead to the transmission of dermatitis. Therefore, the purpose of this study was to evaluate personal hygiene and history of contact with families who have dermatitis and how these relate to the incidence of dermatitis in farmers.

\section{METHODS}

This research used a descriptive observational design and was conducted in the work area of the Puskesmas Meureubo in West Aceh Regency between 5 December 2017 and 8 January 2018 . The data were collected through questionnaires and observation sheets. The condition of dermatitis determined by health workers (doctors). The sample was taken from 1,809 farmers in the work area of the Puskesmas Meureubo in West Aceh District between 2014 and 2016. The number of samples was determined using the Slovin formula, and 95 people were chosen for inclusion in the study using a purposive sampling technique.

Personal hygiene was measured using a questionnaire and direct observation, specifically when the respondent was farming. The incidence of dermatitis was determined based on the observations and recollections of health workers and farmers in the form of physical appearance and symptom (Harahap, 2015). Dermatitis was considered to be "present" if the respondent had physical abnormalities and skin complaints (e.g. itching, red rashes, cuts and scars) and "absent" if the respondent had no physical abnormalities or skin complaints.

Personal hygiene was categorized as "good" if the respondent immediately conducted personal cleaning (personal hygiene) after farming, e.g. immediately taking a shower and not using the same clothes after bathing. It was also considered good hygiene when the farmers wore clean clothes to work and used Personal Protective Equipment (PPE), such as boots. Personal hygiene was categorized as "not good" if the farmer did not immediately conduct personal cleaning (personal hygiene) after farming, if they wore dirty clothes, and if they did not use PPE.

A history of contact with dermatitis sufferers in the family environment was obtained via interviews and categorized based on the contact history between farmers and sufferers during the past year. Contact could refer to direct skin contact or to indirect contact via home appliances and clothing. Contact was classified as "present" if there were family members suffering from dermatitis who had lived together in the past year, and "absent" if there were no family members suffering from dermatitis. Primary data were obtained through interviews and a questionnaire, while secondary data were obtained from health department reports and local health centers.

\section{RESULTS}

The majority of respondents were male (60\%), aged 31-40 years (38\%), and had a low level of education (38\%). The majority of respondents had poor personal hygiene $(61 \%)$, and dermatitis was more common in these farmers compared to farmers with good personal hygiene. The majority of respondents had a history of contact with sufferers of dermatitis within a family environment (66\%) (Table 1).

\section{DISCUSSION}

\section{Characteristics of Respondents}

Age can affect the occurrence of dermatitis in farmers because as human skin ages, it loses the top fat layer and becomes more sensitive and drier. Older skin is also more prone to allergies, sensitivity, and irritation compared to younger skin due to a weakened immune system (Sundararaj, Govindaraju, \& Thangaraj, 2017). Weakening of the immune system in old age is triggered by the diminution of the thymus gland, which makes it harder for skin cells to maintain their moisture levels due to the depletion of the basal layer. In old age, the skin elements that retain water and maintain the texture of the intercellular structure decrease (Nutten, 2015).

Gender can also influence dermatitis as women's skin is more sensitive than men's skin due to differences in hormones and the number of hair follicles and sebaceous glands/sweat glands. Men's skin has a dominant hormone, androgen, which can cause men to sweat more and grow more hair, whereas women's skin is thinner than men's skin, making it more susceptible to damage (Moore et al., 2017). 
Table 1

Distribution of Respondent's Characteristic, Personal Hygiene, and History of Contact with Family Member Who Suffers From Dermatitis at Meureubo Public Health Center, West Aceh District

\begin{tabular}{|c|c|c|c|c|c|c|}
\hline \multirow{3}{*}{ Variable } & \multicolumn{4}{|c|}{ Kejadian Dermatitis Pada Petani } & \multirow{2}{*}{\multicolumn{2}{|c|}{ Total }} \\
\hline & \multicolumn{2}{|c|}{$\mathrm{Ya}$} & \multicolumn{2}{|c|}{ Tidak } & & \\
\hline & $\mathrm{n}$ & $\%$ & $\mathrm{n}$ & $\%$ & $\mathrm{n}$ & $\%$ \\
\hline \multicolumn{7}{|l|}{ Characteristic of Respondent } \\
\hline \multicolumn{7}{|l|}{ Age (Years) } \\
\hline $21-30$ & 20 & 32.00 & 11 & 34.00 & 31 & 32.63 \\
\hline $31-40$ & 24 & 38.00 & 12 & 38.00 & 36 & 37.89 \\
\hline$>40$ & 19 & 30.00 & 9 & 28.00 & 28 & 29.48 \\
\hline \multicolumn{7}{|l|}{ Sex } \\
\hline Male & 36 & 57.00 & 21 & 66.00 & 57 & 60.00 \\
\hline Female & 27 & 43.00 & 11 & 34.00 & 38 & 40.00 \\
\hline \multicolumn{7}{|l|}{ Education } \\
\hline Elementary & 24 & 38.00 & 12 & 38.00 & 36 & 37.89 \\
\hline Middle School & 21 & 33.00 & 10 & 31.00 & 31 & 32.63 \\
\hline High School & 14 & 22.00 & 8 & 25.00 & 22 & 23.16 \\
\hline Higher Education & 4 & 7.00 & 2 & 6.00 & 6 & 6.32 \\
\hline \multicolumn{7}{|l|}{ Personal Hygiene } \\
\hline Good & 25 & 40.00 & 12 & 38.00 & 37 & 38.98 \\
\hline $\mathrm{Bad}$ & 38 & 60.00 & 20 & 62.00 & 58 & 61.02 \\
\hline \multicolumn{7}{|c|}{$\begin{array}{l}\text { History of Contact with Family Member Who } \\
\text { Suffers From Dermatitis }\end{array}$} \\
\hline Yes & 42 & 67.00 & 21 & 66.00 & 63 & 66.32 \\
\hline No & 21 & 33.00 & 11 & 34.00 & 32 & 33.68 \\
\hline Total & 63 & 100.00 & 32 & 100.00 & 95 & 100.00 \\
\hline
\end{tabular}

Education can affect a person's knowledge, and knowledge is an important factor in the formation of behavior. It will be seen from personal hygiene in daily life, especially when working as a farmer, such as using clean clothes, gloves and shoes when farming, and also take a shower immediately after work. Moreover, this behavior will help protect the health of farmers and prevent dermatitis (Ramdan, Ilmiah, \& Rahmat, 2018).

\section{Personal Hygiene and the Occurrence of Dermatitis in Farmers}

The results of the observations indicated that farmers were more likely to have poor personal hygiene than good personal hygiene. Farmers prefer to rest or do other housework, such as washing dishes or sweeping the yard.

According to Penders et al (2014) personal hygiene is personal care with the aim of maintaining health before, during, and after work. The purpose of personal hygiene is to improve health, improve self-confidence, prevent disease, and create beauty.

Farmers are included in the wet work category, which can be defined as activities where workers must immerse their hands in liquid for more than 2 hours a day, need to wear gloves for an appropriate amount of time, or wash their hands more than 20 times a day. Skin diseases such as dermatitis mostly found on the type of work that members are often exposed to the air, such as farmers, fishermen, and health workers (Nutten, 2015).

According to Antonov, Schliemann, \& Elsner (2015), to do a Clean and Healthy Lifestyle (PHBS), several assessments should be done, like eating a balanced diet, families using clean water for their daily needs, families defecating in latrines/toilets that meet health requirements, drinking boiled water, bathing using bath soap, washing hands using soap before eating, washing equipment using soap, and eradicating the sources of disease transmission.

The results of this study are supported by the findings of Dewi, Tina, \& Nurzalmariah (2017), who stated that poor personal hygiene can cause dermatitis by allowing germs to multiply. The results of this study are also supported by Susanty (2015), who stated that poor personal hygiene can cause skin disease, e.g. sweaty clothing can allow germs to breed easily. Dewi, Tina, \& 
Nurzalmariah (2017) also mentioned that personal hygiene can influence dermatitis, while Bhuiyan, Sikder, Wadud, Ahmed, \& Faruq (2016) stated that personal hygiene influences skin disease. Similarly, Bonamonte et al (2019) found that poor personal hygiene was a risk factor for dermatitis.

\section{Contact with Family Members with Dermatitis and the Occurrence of Dermatitis in Farmers}

The field observations suggested that the respondents who had contact with family members suffering from dermatitis were more likely to experience dermatitis themselves compared to the respondents who did not have a history of contact with family members suffering from dermatitis. Al-Otaibi \& Alqahtani (2015) also revealed that one of the risks associated with the occurrence of dermatitis was contact with dermatitis sufferers. Some respondents with no history of contact with family members suffering from dermatitis still experienced dermatitis themselves, however, possibly due to a lack of good personal hygiene (Kantor \& Silverberg, 2017). Safriyanti, Lestari, \& Ibrahim (2016) stated that certain jobs had a higher risk of dermatitis, such as farming, jobs in the furniture industry, carpentry, painting, hairdressing, and jobs in the textile industry. The results of their study also showed that there was a significant relationship between personal hygiene and a history of contact with dermatitis sufferers. The same results were also found in a study by Chafidz \& Dwiyanti (2018) who stated that there was a correlation between duration of contact and occurrence of dermatitis. This condition according to the research conducted by Herwanto \& Hutomo (2016) that duration of contact will provide a great risk for the spread of skin diseases, such as dermatitis.

According to Moore et al (2017), bathing and using soap at least two times a day (more often when working in dirty or sweaty places), avoid using clothes, towels, blankets, bath soap, and gloves in congregation can decrease the risk of dermatitis infection. The study also mentioned that the factors causing contact dermatitis can be divided into direct causes (characteristics of media contact) and indirect causes (characteristics of host). The results of the current study are also supported by research conducted by Sasseville, Alfalah, \& Lacroix (2015), who mentioned that contact with dermatitis sufferers can cause dermatitis.

Skin disease can be caused by several factors, such as environmental factors, exposure characteristics, agent characteristics, and individual factors like age, sex, and personal hygiene (Anshar, Pramuningtyas, \& Usdiana, 2016). Inadequate personal hygiene can cause fungal, bacterial, viral, and parasitic infections, as well as skin disorders and other complaints. If working conditions are dirty and moist, this can cause skin diseases to develop more easily (Dewi, Tina, \& Nurzalmariah, 2017; Moore et al., 2017)

\section{CONCLUSION}

The majority of respondents were male, aged 31-40 years, and had a low level of education. Farmer with poor hygiene and a history of contact with family members who suffered from dermatitis were more likely to suffer from dermatitis themselves.

\section{CONFLICT OF INTEREST}

The authors declare that no conflict of interest in this study.

\section{ACKNOWLEDGMENT}

I would like to thank the Health Office of West Aceh District Health Office, the public health center, and all the lecturers of public health at Universitas Teuku Umar who involved and contributed in this research.

\section{REFERENCES}

Aceh Provincial Health Office. (2016). Aceh Province health profile 2016. Nanggroe Aceh Darussalam: Aceh Provincial Health Office.

Al-Otaibi, S. T., \& Alqahtani, H. A. M. (2015). Review: management of contact dermatitis. Journal of Dermatology \& Dermatologic Surgery, $\quad 19(2), \quad 86-91$. https://doi.org/10.1016/j.jdds.2015.01.001

Alex, A. A., Longinus, N. K., Olatunde, A. M., \& Chinedu, N. V. (2018). Pesticides related knowledge, attitude and safety practices among small-scale vegetable farmers in lagoon wetlands, Lagos, Nigeria. Journal of Agriculture and Environment for International Development, 112(1), 81-99. https://doi.org/10.12895/jaeid.20181.697

Anshar, R., Pramuningtyas, R., \& Usdiana, D. (2016). Hubungan pekerja basah dengan kejadian dermatitis kontak akibat kerja pada petugas kesehatan di Rumah Sakit $X$ Tanjung, Tabalong, Kalimantan Selatan. Biomedika, $\quad$ 8(2), 25-30. 
https://doi.org/10.23917/biomedika.v8i2.291 3

Antonov, D., Schliemann, S., \& Elsner, P. (2015). Hand dermatitis: a review of clinical features, prevention and treatment. American Journal of Clinical Dermatology, 16(4), 257-270. https://doi.org/10.1007/s40257-015-0130-z

Bhuiyan, M. S. I., Sikder, M. S., Wadud, F., Ahmed, S., \& Faruq, M. O. (2016). Pattern of occupational skin diseases among construction workers in Dhaka city. Bangladesh Medical Journal, 44(1), 11-15. https://doi.org/10.3329/bmj.v44i1.26338

Bonamonte, D., Filoni, A., Vestita, M., Romita, P., Foti, C., \& Angelini, G. (2019). The role of the environmental risk factors in the pathogenesis and clinical outcome of atopic dermatitis. BioMed Research International, 2019. https://doi.org/10.1155/2019/2450605

Chafidz, M., \& Dwiyanti, E. (2018). Hubungan lama kontak, jenis pekerjaan dan penggunaan APD dengan kejadian dermatitis kontak pada pekerja tahu, Kediri. The Indonesian Journal of Occupational Safety and Health, 6(2), $156-165$.

https://doi.org/10.20473/ijosh.v6i2.2017.156165

Chandarakesan, A., Muruhan, S., \& Sayanam, R. R. A. (2018). Morin inhibiting photocarcinogenesis by targeting ultravioletB-induced oxidative stress and inflammatory cytokines expression in Swiss Albino Mice. International Journal of Nutrition, Pharmacology, Neurological Diseases, 8, 41-46. https://doi.org/10.4103/ijnpnd.ijnpnd

Dewi, S., Tina, L., \& Nurzalmariah, W. (2017). Hubungan personal hygiene, pengetahuan dan pemakaian sarung tangan dengan kejadian penyakit dermatitis kontak pada pemulung sampah Ditpa Puuwatu Kota Kendari tahun 2016. Jurnal Ilmiah Mahasiswa Kesehatan Masyarakat Unsyiah, 2(6), 1-9.

Harahap, M. (2015). Ilmu penyakit kulit. Jakarta: Hipokrates.

Herwanto, N., \& Hutomo, M. (2016). Retrospective study: management of atopic dermatitis. Berkala Ilmu Kesehatan Kulit Dan Kelamin, 28(1), 45-54.

Kadivar, S., \& Belsito, D. V. (2015). Occupational dermatitis in health care workers evaluated for suspected allergic contact dermatitis. Dermatitis, 26(4), 177-183. https://doi.org/10.1097/DER.0000000000000 124
Kantor, R., \& Silverberg, J. I. (2017). Environmental risk factors and their role in the management of atopic dermatitis. Expert Review Clinical Immunology, 13(1), 15-26. https://doi.org/10.1016/j.physbeh.2017.03.04 0

Malik, M., \& English, J. (2015). Irritant hand dermatitis in health care workers. Occupational Medicine, 65(6), 474-476. https://doi.org/10.1093/occmed/kqv067

Mekonnen, T. H., Yenealem, D. G., \& Tolosa, B. M. (2019). Self-report occupational-related contact dermatitis: prevalence and risk factors among healthcare workers in Gondar town, Northwest Ethiopia, 2018 - a crosssectional study. Environmental Health and Preventive Medicine, 24(1), 1-9. https://doi.org/10.1186/s12199-019-0765-0

Moore, K. J., Chen, C., Lee, D. J., LeBlanc, W. G., Fleming, L. E., \& Caban-Martinez, A. J. (2017). Epidemiology of occupational skin conditions in emerging U.S. Green Collar Workforce. Dermatitis, 27(3), 155-157. https://doi.org/10.1016/j.physbeh.2017.03.04 0

Mrema, E. J., Ngowi, A. V., Kishinhi, S. S., \& Mamuya, S. H. (2017). Pesticide exposure and health problems among female horticulture workers in Tanzania. Environmental Health Insights, 11. https://doi.org/10.1177/1178630217715237

Negatu, B., Kromhout, H., Mekonnen, Y., \& Vermeulen, R. (2016). Use of chemical pesticides in Ethiopia: a cross-sectional comparative study on knowledge, attitude and practice of farmers and farmworkers in three farming systems. Annals of Occupational Hygiene, 60(5), 551-566. https://doi.org/10.1093/annhyg/mew004

Nutten, S. (2015). Atopic dermatitis: global epidemiology and risk factors. Annals of Nutrition and Metabolism, 66(Suppl 1), 816. https://doi.org/10.1159/000370220

Penders, J., Gerhold, K., Thijs, C., Zimmermann, K., Wahn, U., Lau, S., ... Wahn, U. (2014). New insights into the hygiene hypothesis in allergic diseases. Gut Microbes, 5(2), 239244. https://doi.org/10.4161/gmic.27905

Rahman, A., Sultana, A., Rahman, K., \& Bilgrami, S. (2015). Prevalence of occupational contact dermatitis, knowledge and adaption of preventive measures by chemical industries workers of Pune: an observational study. Journal of Environmental and Occupational Science, $\quad 4(1), \quad 27-33$. 
https://doi.org/10.5455/jeos.20141106012039

Ramdan, I. M., Ilmiah, S. H., \& Rahmat, A. F. (2018). Occupational irritan contact dermatitis among shipyard workers in Samarinda, Indonesia. Jurnal Kesehatan Masyarakat, 14(2), 239-246. https://doi.org/10.15294/kemas.v14i2.13417

Safriyanti, S., Lestari, H., \& Ibrahim, K. (2016). Hubungan personal hygiene, lama kontak dan riwayat penyakit kulit dengan kejadian dermatitis kontak pada petani rumput laut di Desa Akuni Kecamatan Tinanggea Kabupaten Konawe Selatan Tahun 2016. Jurnal Ilmiah Mahasiswa Kesehatan Masyarakat, 1(3), 1-10.

Salawati, L. (2015). Penyakit akibat kerja dan pencegahan. Jurnal Kedokteran Syiah Kuala, 15(2), 91-95. https://doi.org/10.1523/JNEUROSCI.064408.2008

Sasseville, D., Alfalah, M., \& Lacroix, J.-P. (2015). "Parabenoia" debunked, or "who's afraid of parabens?". Dermatitis, 26(6), 254259.

Sundararaj, T., Govindaraju, M., \& Thangaraj, B. (2017). A study of 300 cases of allergic contact dermatitis. International Journal of Research in Dermatology, 3(1), 13-19. https://doi.org/10.18203/issn.2455-

4529.intjresdermatol20164409

Susanty, E. (2015). Hubungan personal hygiene dan karakteristik individu terhadap kejadian dermatitis pada petani rumput laut di Dusun Puntondo Kabupaten Takalar Undergraduated Thesis. Faculty of Public Health. Hasanuddin University. https://doi.org/10.1145/3132847.3132886

Wardani, H. K., Mashoedojo, \& Bustamam, N. (2018). Related factors to occupational contact dermatitis among project workers of airport. The Indonesian Journal of Occupational Safety and Health, 7(2), 249259.

West Aceh District Health Office. (2017). West Aceh health profile 2016. Meulaboh: West Aceh District Health Office. 